\title{
Effect of iron addition on the crystal structure of the $\alpha$-AlFeMnSi phase formed in the quaternary Al-Fe-Mn-Si system ${ }^{(\cdot)}$
}

\author{
P. Orozco-González*, M. Castro-Román**, J. López-Cuevas**, A. Hernández-Rodríguez**, \\ R. Muñiz-Valdez***, S. Luna-Álvarez*** y C. Ortiz-Cuellar***
}

\begin{abstract}
Cubic and hexagonal $\alpha$-phases, formed during thermal analysis experiments and specific isothermal treatments, have been analyzed for a series of Al-Mn-Si alloys with different iron contents. In these alloys, the Fe/Mn weight ratio was varied from 0.1 to 8.4. This study shows that in $\mathrm{Al}-\mathrm{Fe}-\mathrm{Mn}$-Si alloys with $\mathrm{Fe} / \mathrm{Mn}$ weight ratios up to 4, the $\alpha$-phase has a cubic crystal structure, while in alloys with a Fe/Mn weight ratio of 5.3 or more, the $\alpha$-phase has a hexagonal crystal structure. Hence, the critical Fe/Mn weight ratio for the cubic to hexagonal crystal structure transition falls between 4 and 5.3 for the studied alloys.
\end{abstract}

\section{Efecto de la adición de hierro sobre la estructura cristalina de la fase $\alpha$-AlFeMnSi formada en el sistema cuaternario Al-Fe-Mn-Si}

\begin{abstract}
Resumen
Las fases $\alpha$ de estructura cristalina cúbica y hexagonal, formadas durante los ensayos de análisis térmico y tratamientos isotérmicos específicos, han sido analizadas para una serie de aleaciones $\mathrm{Al}-\mathrm{Mn}-\mathrm{Si}$ con diferente contenido de hierro. En estas aleaciones, la relación en peso Fe/Mn se varió de 0,1 a 8,4. Este estudio muestra que las aleaciones Al-13,4Si-1,1 Mn-Fe con relación en peso Fe/Mn menor o igual a 4, la fase $\alpha$ presenta estructura cristalina cúbica, mientras que en aleaciones con una relación Fe/Mn igual o mayor a 5,3, la fase $\alpha$ presenta estructura cristalina hexagonal. Por lo tanto, la relación crítica Fe/Mn para la transición de estructura cristalina de cúbica a hexagonal se encuentra entre 4 y 5,3 para las aleaciones estudiadas.
\end{abstract}

Palabras clave

Aleaciones de aluminio; Compuestos intermetálicos Al-Fe-Mn-Si; Difracción de rayos X; Tipo de estructura cristalina.

\section{INTRODUCTION}

Commercial Al-Si alloys are of special interest to the aluminum industry due to their wide variety of automotive applications. These alloys always contain Iron impurities, which are detrimental to their mechanical properties and extrusion characteristics. This is attributed to the formation of different Iron-containing intermetallic phases ${ }^{[1-4]}$. Around 17 different intermetallic phases, with general composition of either aluminium-iron or $\mathrm{Al}-\mathrm{Fe}-\mathrm{Si}$, have been summarized ${ }^{[5]}$.
The ternary Al-Fe-Si system has been widely studied; experimental data pertaining to the intermetallic phases present in this system have been summarized in well documented review papers $^{[2 \text { and } 6-8]}$. In Al-Si alloys, it has been reported that $\alpha_{b c c}-A 1 F e M n S i$ and $\beta$-AlFeSi phases form when the $\mathrm{Fe} / \mathrm{Mn}$ weight ratio is high, around 4. However, when this ratio is low, around 2, only the $\alpha_{\mathrm{bcc}}$-AlFeMnSi phase with Chinese script, star-like and polyhedral morphologies is formed, which has an increased sedimentation tendency ${ }^{[9]}$. For Al-Si alloys with a low Fe/Mn weight ratio of

\footnotetext{
(•) Trabajo recibido el día 13 de diciembre de 2010 y aceptado en su forma final el día 31 de mayo de 2011.

* Facultad de Ingeniería, Universidad Autónoma de Zacatecas, Zacatecas, México. Corresponding author: e-mail: orozco pilar@yahoo.com.mx, Tel.: +52 4929220827 .

** CINVESTAV-Saltillo, Carretera Saltillo-Monterrey km. 13.5, P.O. Box, 25000, Saltillo, Coahuila, México.

*** Facultad de Ingeniería, Universidad Autónoma de Coahuila, Edificio D Unidad-Campo Redondo, Saltillo, Coahuila, México.
} 
1.2 , the presence of cubic $\alpha$ and $\alpha_{\text {bcc }}-A l F e M n S i$ phases, the latter described as $\mathrm{Al}_{19} \mathrm{Fe}_{4} \mathrm{MnSi}_{2}$, has been reported ${ }^{[5]}$. The formation of a hexagonal $\alpha_{h}$-AlFeMnSi phase, with a formula of $\mathrm{Al}_{8} \mathrm{Fe}_{2} \mathrm{Si}$, has also been reported ${ }^{[6,10}$ and 11$]$. Tibballs et al. ${ }^{[12]}$ studied a set of eight alloys of the Al-(6-8)Si(0.4-3.5)Fe-(0.1-3.6) Mn system. They reported the precipitation of a cubic $\alpha_{c}-A l F e M n S i$ phase in alloys with a $\mathrm{Fe} / \mathrm{Mn}$ weight ratio up to 8.3, whereas the $\alpha_{\mathrm{h}}$-AlFeMnSi was the stable phase in alloys with a $\mathrm{Fe} / \mathrm{Mn}$ ratio equal or higher than 12.5.

From the point of view of the improvement of the available thermodynamic databases, the study of Al-Fe-Mn-Si system and other alloy systems is gaining importance in basic and applied research. Ravi and Wolverton ${ }^{[13]}$ made a critical comparison of the two commercially available Al-alloy thermodynamic databases: Thermotech and Computherm. They observed some differences in the databases with regard to the intermetallic compounds involving iron, manganese, chromium, and zinc. Thus, they suggested making future improvements in both databases. Additionally, it has been reported that the type of intermetallic phases that are formed strongly depends on the kinetic aspects associated with the cooling conditions employed ${ }^{[14]}$.

In contrast to the ternary aluminium-silicon-iron system, knowledge on the quaternary Al-Fe-Mn-Si system is sparse. The analysisof previously published relevant scientific literature indicates that the determination of the solid-state and solid-liquid equilibria of intermetallic phases in the Al-Fe-Mn-Si system is of the utmost importance. This information will enhance the available data concerning the effect of iron content on the crystal structure, morphology and chemical composition of the Fe-containing phases formed in alloys belonging to this system. This work was performed in order to provide additional experimental information about the domains of existence of $\alpha_{s c}, \alpha_{b c c}$ and $\alpha_{h}$-AlFeMnSi phases in a series of Al-13.4Si-1.1Mn(0.15-10.1) Fe alloys.

\section{EXPERIMENTAL PROCEDURE}

\subsection{Materials}

The aluminum alloys were prepared starting from aluminium ingots of commercial purity $(99.79 \%)^{1}$; the main impurities present in these ingots were: $0.14 \% \mathrm{Fe}$ and $0.05 \% \mathrm{Si}$. The added alloying elements were: $\mathrm{Fe}(99.98 \%), \mathrm{Mn}$ (99.95\%), and silicon of commercial grade. The chemical composition of the alloys (see Table I) was determined by inductively coupled plasma emission spectroscopy (ICP) with an Iris Intrepid spectrometer.

Table I. Chemical composition of the
aluminum alloys

Tabla I. Composición química de las aleaciones de aluminio

\begin{tabular}{cccccc}
\hline Alloy & Al & Si & Mn & Fe & Fe/Mn ratio \\
\hline 1 & 85.4 & 13.3 & 1.2 & 0.15 & 0.1 \\
2 & 84.2 & 13.5 & 1.1 & 1.2 & 1.1 \\
3 & 82.8 & 13.4 & 1.1 & 2.7 & 2.4 \\
4 & 81.1 & 13.4 & 1.1 & 4.4 & 4.0 \\
5 & 80.4 & 13.3 & 1.0 & 5.3 & 5.3 \\
6 & 78.2 & 13.5 & 1.2 & 7.1 & 5.9 \\
7 & 77.0 & 13.4 & 1.1 & 8.5 & 7.7 \\
8 & 75.1 & 13.6 & 1.2 & 10.1 & 8.4 \\
\hline
\end{tabular}

\subsection{Thermal analysis}

In order to determine the solidification sequence as well as the onset temperature, $T_{p}$, for the intermetallic phase formation, thermal analysis curves were obtained by using an experimental device similar to the one used by Bäckerud et al. ${ }^{[14]}$. First, the alloy was melted and heated to $800^{\circ} \mathrm{C}$ under an ambient air atmosphere in a gas furnace. Then, the molten alloy was poured into a graphite cup preheated to $900^{\circ} \mathrm{C}$ in an electric furnace. Subsequently, in order to achieve thermal equilibrium conditions, the melt was kept at $900^{\circ} \mathrm{C}$ for $120 \mathrm{~s}$ in the graphite cup inside the electrical furnace. Finally, the sample was cooled down to room temperature at a rate of $1^{\circ} \mathrm{C} / \mathrm{s}$.

The alloy's temperature was measured with two K-type thermocouples placed on the cup's lid, as shown in figure 1 . The precision of the thermocouples was assessed by measuring the melting temperature of pure aluminum $\left(659.9^{\circ} \mathrm{C}\right)$. Temperature-time data were recorded using a 16-bit resolution DaqTemp $14 \mathrm{~A}$ card linked to a computer.

\subsection{Isothermal treatments}

Based on the values of $T_{p}$ obtained for the formed intermetallics (see Table II $)^{p}$, the alloys were subjected to an isothermal treatment at a temperature set $\sim 15^{\circ} \mathrm{C}$ below $T_{p}$, which is hereinafter denominated as $T_{s}$. The purpose of this isothermal treatment was 

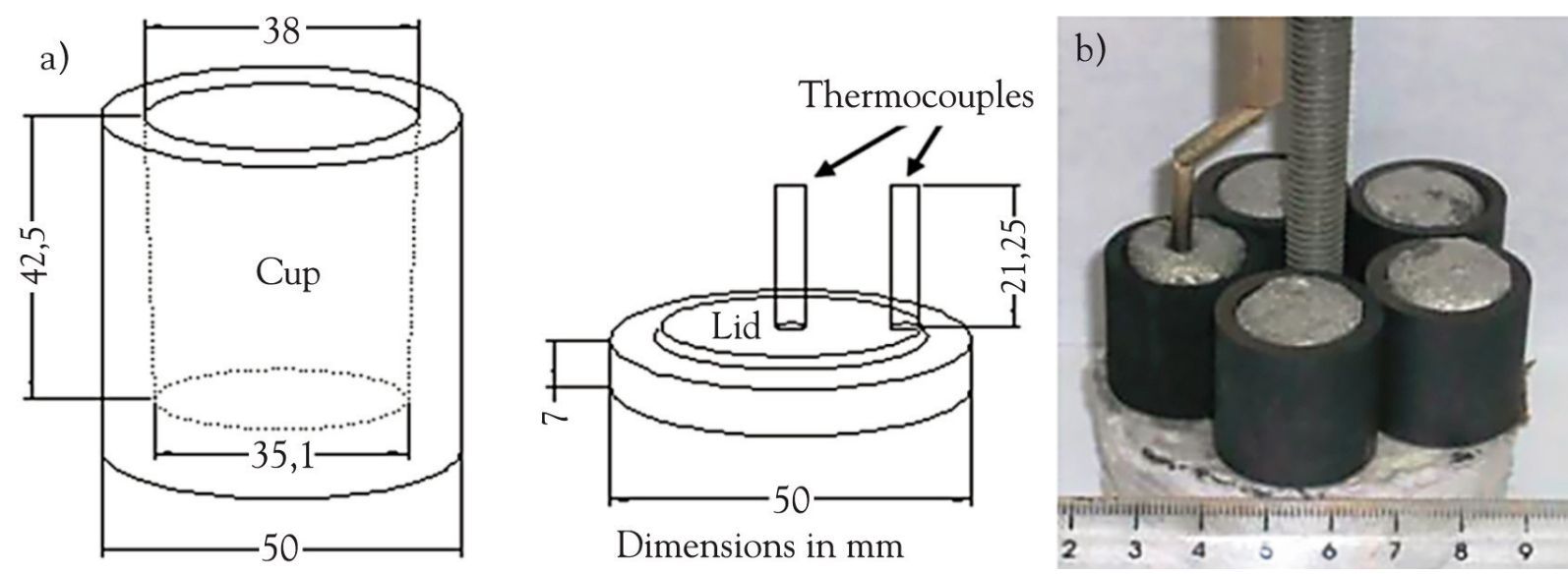

Figure 1. a) Schematic illustration of the graphite cup and lid used to carry out the thermal analysis experiments, and b) experimental setup used for the isothermal treatments.

Figura 1. a) Ilustración esquemática de la copa de grafito usada para llevar a cabo los ensayos de análisis térmico y b) dispositivo experimental usado para los tratamientos isotérmicos.

to allow the intermetallic particles to grow and settle down toward the bottom of the sample. Each sample was $0.019 \mathrm{~m}$ in diameter and $0.025 \mathrm{~m}$ in height and was placed inside a graphite crucible having a wall thickness of $0.003 \mathrm{~m}$. A set of five crucibles, shown in figure 1 , was heated in an electric furnace under ambient air atmosphere; the furnace temperature was controlled with a K-type thermocouple placed inside one of the samples. The heat treatment was carried out at $900{ }^{\circ} \mathrm{C}$ for $1800 \mathrm{~s}$, subsequently cooled down to $T_{\mathrm{s}}$ at $0.017^{\circ} \mathrm{C} / \mathrm{s}$ and then held at $T_{s}$ for $15 \mathrm{~h}$. At the end of the isothermal treatment, the samples were quenched in a water bath at $\sim 20^{\circ} \mathrm{C}$. Due to the small size of the samples, the water quenching effectively retained the solid-liquid microstructure. Finally, the formed intermetallics were extracted by dissolving the aluminum matrix in a $15 \%(\mathrm{~V} / \mathrm{V}) \mathrm{HCl}$ aqueous solution.

\subsection{Intermetallics characterization}

The extracted intermetallics were characterized by using a JEOL JSM-6300 Scanning Electron Microscope (SEM) equipped with an energy dispersive X-ray spectrometer (EDS). The EDS spectra were recorded with an acquisition time of $30 \mathrm{~s}$. For the crystal structure determination, the extracted particles were ground and then analyzed by X-ray diffraction (XRD) using a Phillips X' Pert 3040 XRD apparatus with $\mathrm{Cu} \mathrm{K}_{\alpha}$ radiation. The lattice parameters were obtained by Nelson-Riley analysis.

\section{RESULTS AND DISCUSSION}

Figure 2 shows the cooling curves obtained for alloys 4 and 6 cooled at $\sim 1^{\circ} \mathrm{C} / \mathrm{s}$; the first derivative of both cooling curves is also included. The first slope change observed in the cooling curves is associated with the precipitation of an intermetallic phase ( $\alpha$-phase); the corresponding $T_{p}$ was estimated with the aid of an associated peak appearing in the first derivative curves. The arrows on the graphs indicate the temperature at which the $\alpha$-phase is formed in both alloys. The corresponding $T_{p}$ values are listed in table II.

It is worth mentioning that a second slope change occurring in the cooling curves in the temperature range of $610-620^{\circ} \mathrm{C}$ and the associated peak in the corresponding first derivative curve corresponded to the formation of the $\beta$-phase. However, due to the small amount of this phase formed in the thermal analysis samples and the fact that it was mixed with the previously formed $\alpha$-phase, the study of its formation was difficult to undertake, and thus, it is not reported in the present work. Furthermore, $\beta$-phase is not present in the isothermal treated samples.

\subsection{Simple cubic $\alpha_{\mathrm{sc}}$ - AlFeMnSi phase}

The intermetallics extracted from the samples of alloy 1 , after isothermal heat treatment at $595^{\circ} \mathrm{C}$, were analyzed by XRD (Fig. 3). As can be observed, all peaks correspond to the $\mathrm{Al}_{50} \mathrm{Mn}_{12} \mathrm{Si}_{7}$ phase (JCPDS card number 071-2182); this phase exhibits a simple cubic (sc) crystal structure with a Pm3 


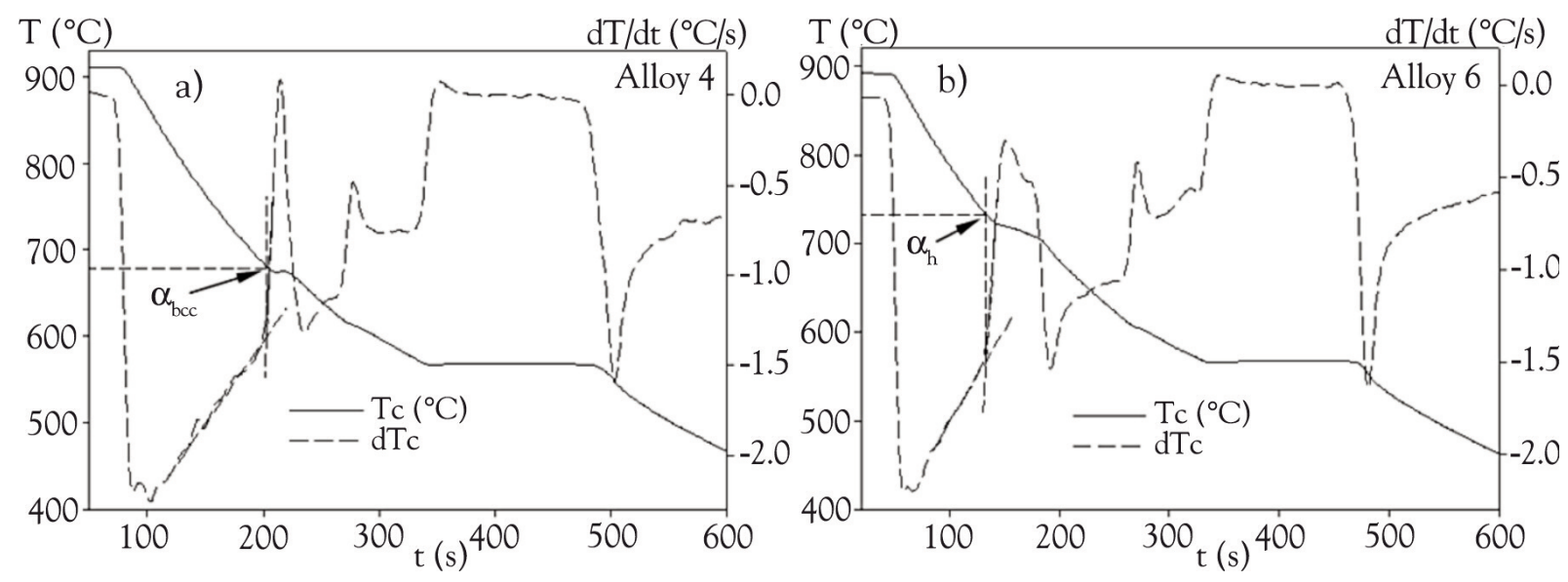

Figure 2. Cooling curves (solid lines), and their first derivative (dashed lines), obtained for alloys 4 a) and 6 b).

Figura 2. Curvas de enfriamiento (líneas continuas) y su correspondiente primera derivada (línea discontinua), obtenidas para las aleaciones 4 a) y 6 b).

space group ${ }^{[15]}$. In this work, however, according to the EDS data given in table II, the extracted intermetallic actually corresponds to the $\alpha_{\text {sc }}-\mathrm{Al}_{34.1} \mathrm{FeMn}_{8.5} \mathrm{Si}_{6.16}$ formula, with a $\mathrm{Fe} / \mathrm{Mn}$ weight ratio of $\mathrm{O} .12$, and a total concentration of transition metals $(\mathrm{Fe}+\mathrm{Mn})$ of $32.4 \%$. For comparison, alloy 1 had a Fe/Mn weight ratio of 0.1 and a total transition metal concentration of $1.3 \%$, according to table I. The irregular and polyhedral morphologies of the $\alpha_{\mathrm{sc}}$-AlFeMnSi phase observed on the SEM in the as-cast and in the isothermally-treated alloy 1 , are shown in figures 4 a) and 4 b), respectively.

Figure 3 shows the XRD pattern of the $\mathrm{Al}_{50} \mathrm{Mn}_{12} \mathrm{Si}_{7}$ phase (JCPDS card number 071-2182) in comparison with the experimental XRD pattern of the $\alpha_{\mathrm{sc}}-\mathrm{Al}_{34.1} \mathrm{FeMn}_{8.5} \mathrm{Si}_{6.16}$ phase. It is observed that both patterns show similar peaks, in some cases the peaks intensity and the $2 \theta$ angles change in a little extent. This behavior has been attributable to the substitution

Table II. Chemical composition and structural data of extracted intermetallic phases, determined from the results of the SEM/EDS and XRD analyses

Tabla II. Composición química e información cristalina de las fases cristalinas extraídas, determinadas mediante análisis de MEB/EDS y DRX

\begin{tabular}{|c|c|c|c|c|c|c|c|c|c|}
\hline \multirow{2}{*}{ Alloy } & \multirow{2}{*}{$\begin{array}{c}T_{p} T_{s} \\
\left({ }^{\circ} \mathrm{C}\right)\left({ }^{\circ} \mathrm{C}\right)\end{array}$} & \multirow{2}{*}{$\begin{array}{c}\text { AIFeMnSi } \\
\text { Intermetalli } \\
\text { c }\end{array}$} & \multicolumn{4}{|c|}{$\begin{array}{l}\text { Composition from } \\
\text { SEM/EDS }\end{array}$} & \multirow{2}{*}{$\begin{array}{c}\text { Fe/Mn } \\
\text { weight } \\
\text { ratio }\end{array}$} & \multirow{2}{*}{ Formula } & \multirow{2}{*}{$\begin{array}{l}\text { Lattice } \\
\text { Parameter } \\
\qquad(A)\end{array}$} \\
\hline & & & Al & Si & $\mathrm{Fe}$ & $\mathrm{Mn}$ & & & \\
\hline 1 & 610595 & $\alpha_{\mathrm{sc}}$ & 56.90 & 10.69 & 3.45 & 28.95 & 0.12 & $\mathrm{Al}_{34.1} \mathrm{FeMn}_{8.5} \mathrm{Si}_{6.16}$ & $a=12.648$ \\
\hline 2 & 655640 & $\alpha_{b c c}$ & 58.20 & 10.24 & 9.77 & 21.80 & 0.45 & $\mathrm{Al}_{12.3} \mathrm{FeMn}_{2.27} \mathrm{Si}_{2.1}$ & $a=12.603$ \\
\hline 3 & 666651 & $\alpha_{b c c}$ & 58.03 & 10.14 & 14.08 & 17.75 & 0.79 & $\mathrm{Al}_{8.5} \mathrm{FeMn}_{1.28} \mathrm{Si}_{1.43}$ & $a=12.587$ \\
\hline 4 & 679664 & $\alpha_{b c c}$ & 57.93 & 10.07 & 18.61 & 13.38 & 1.39 & $\mathrm{Al}_{8.8} \mathrm{Fe}_{1.36} \mathrm{MnSi}_{1.47}$ & $a=12.535$ \\
\hline 5 & 702687 & $\alpha_{h}$ & 53.82 & 12.25 & 27.72 & 6.22 & 4.45 & $\mathrm{Al}_{17.6} \mathrm{Fe}_{4.39} \mathrm{MnSi}_{3.85}$ & $a=12.435, c=26.30$ \\
\hline 6 & 732717 & $\alpha_{h}$ & 53.27 & 12.51 & 26.46 & 7.76 & 3.41 & $\mathrm{Al}_{14.0} \mathrm{Fe}_{3.36} \mathrm{MnSi}_{3.15}$ & $a=12.39, c=26.203$ \\
\hline 7 & 738723 & $\alpha_{h}$ & 53.64 & 12.29 & 26.48 & 7.60 & 3.48 & $\mathrm{Al}_{14.4} \mathrm{Fe}_{3.43} \mathrm{MnSi}_{3.17}$ & $a=12.37, c=26.167$ \\
\hline 8 & 745730 & $\alpha_{h}^{\prime \prime}$ & 53.98 & 12.71 & 26.92 & 6.38 & 4.22 & $\mathrm{Al}_{17.2}^{1.4} \mathrm{Fe}_{4.15}{ }^{0.4} \mathrm{MnSi}_{3.9}$ & $a=12.359, c=26.14$ \\
\hline
\end{tabular}

$T_{p}$ - Onset temperature for the intermetallic phase formation, $T_{s}-$ Isothermal treatment temperature.

${ }^{a}$ Average of eight SEM/EDS analyses of the extracted particles, for each alloy. 


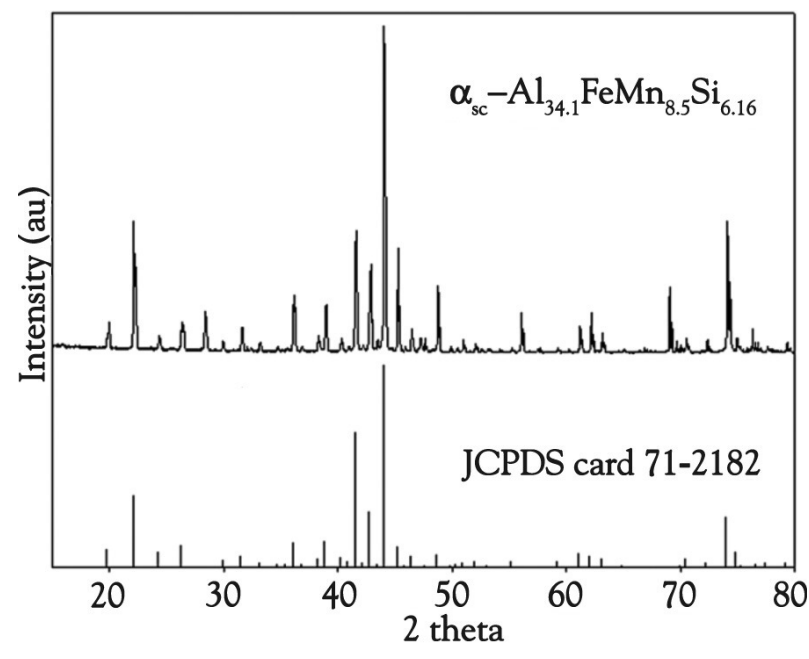

Figure 3. XRD pattern obtained for the $\alpha_{\text {sc }}-\mathrm{Al}_{34.1} \mathrm{FeMn}_{8.5} \mathrm{Si}_{6.16}$ phase extracted from alloy 1 .

Figura 3. Difractograma de DRX obtenido de la fase $\alpha_{c s}-\mathrm{Al}_{34.1} \mathrm{FeMn}{ }_{8.5} \mathrm{Si}_{6.16}$ extraída de la aleación 1. of manganese atoms by Iron atoms ${ }^{[4}$ and 16] in the lattice sites of the crystal structure. Similar results were observed for the $\alpha_{b c c}$ and $\alpha_{h}$-AlFeMnSi phases, shown in the following paragraphs. All the SEM/EDS and XRD analysis results are summarized in table II for the extracted intermetallic phases.

\subsection{Body-centered cubic $\alpha_{b c c}$ - AlFeMnSi phase}

$\alpha_{\mathrm{hcc}}$-AlFeMnSi was the primary phase precipitated in alloys 2 to 4 during isothermal holding at $T_{s}$ (Table II). The XRD pattern of the intermetallic particles extracted from alloy 4 is shown in figure 5 . As can be observed, all peaks could be indexed according to the JCPDS card number 71-4015, which corresponds to the $\mathrm{Al}_{17} \mathrm{Fe}_{3.2} \mathrm{Mn}_{0.8} \mathrm{Si}_{2}$ phase. This phase exhibits a bodycentered cubic ( $\mathrm{bcc}$ ) crystal structure and belongs to the $\operatorname{Im} 3$ space group ${ }^{[17]}$. In the case of alloy 4 , according to the EDS analysis given in table II, the extracted

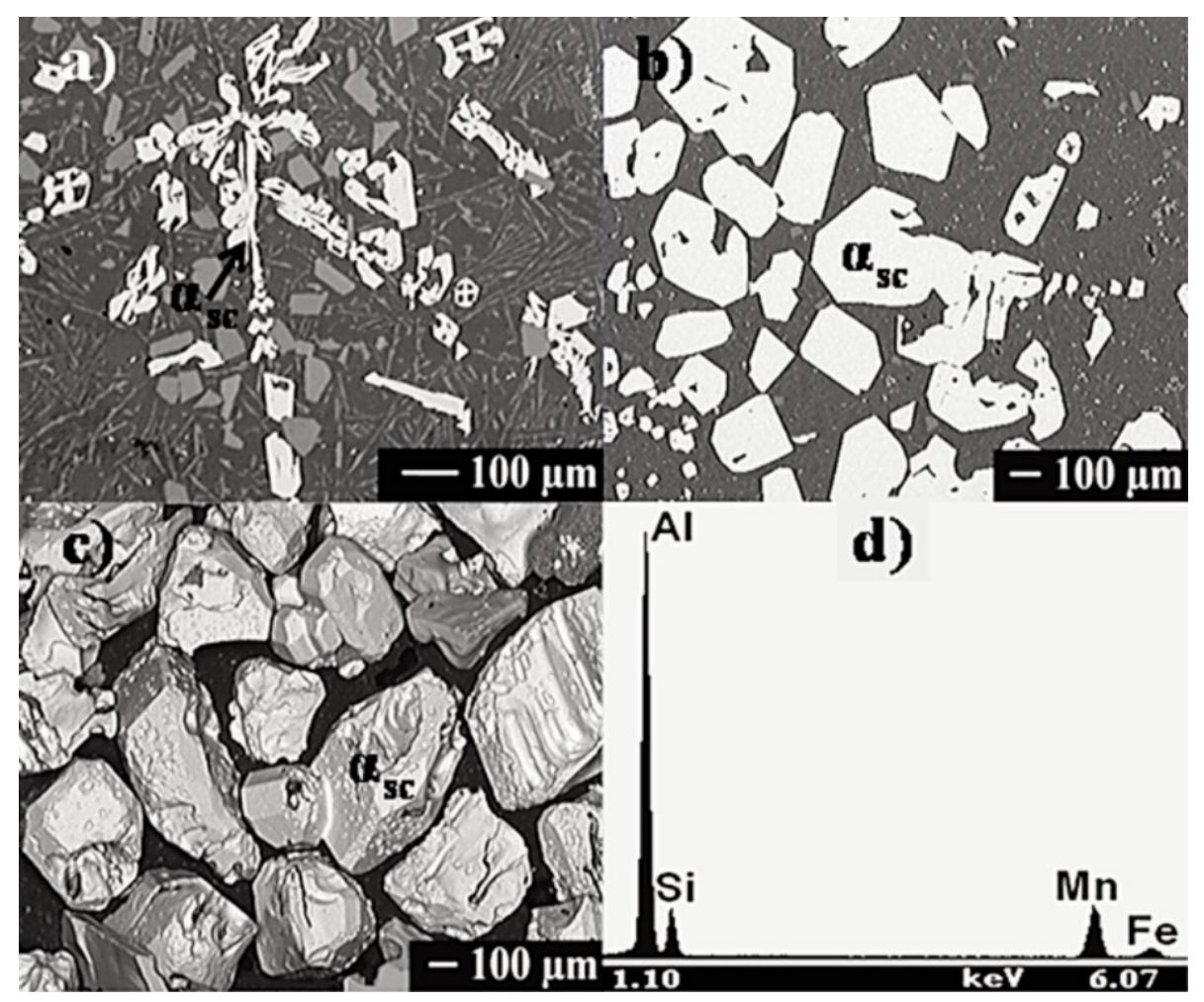

Figure 4. SEM micrographs showing the morphology of the $\alpha_{\mathrm{sc}}$ AlFeMnSi phase found in alloy 1 , as-cast (a), isothermally-treated at $595^{\circ} \mathrm{C}(\mathrm{b})$ and of extracted $\alpha_{\mathrm{sc}}$ particles (c). EDS spectra of extracted $\alpha_{\text {sc }}$ particles (d).

Figura 4. Micrografías de MEB mostrando la morfología de la fase $\alpha_{c s}{ }^{-}$ AlFeMnSi encontrada en la aleación 1, en condición de colada (a), tratada isotérmicamente a $595^{\circ} \mathrm{C}$ (b) y partículas de $\alpha_{c s}$ extraídas (c). Espectro de EDS obtenido de las partículas de $\alpha_{c S}$ extraídas (d). 


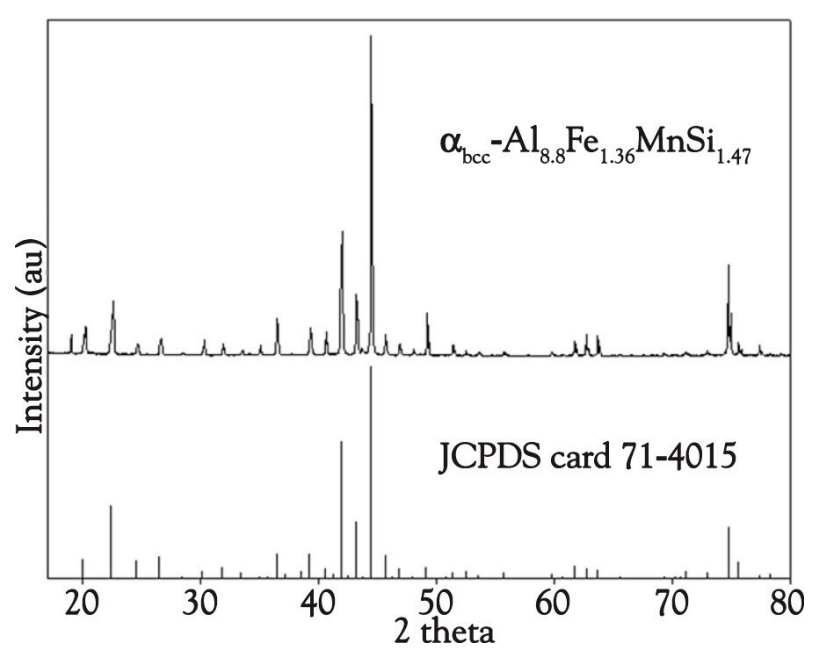

Figure 5. XRD pattern obtained for the $\alpha_{\mathrm{bcc}}-\mathrm{Al}_{8.8} \mathrm{Fe}_{1.36} \mathrm{MnSi}_{1.47}$ phase extracted from alloy 4 .

Figura 5. Difractograma de $D R X$ obtenido de la fase $\alpha_{c c c}-\mathrm{Al}_{8.8} \mathrm{Fe}_{1.36} \mathrm{MnSi}_{1.47}$ extraída de la aleación 4. intermetallic particles actually corresponded to the $\alpha_{\text {bcc }}-\mathrm{Al}_{8.8} \mathrm{Fe}_{1.36} \mathrm{MnSi}_{1.47}$ formula. The chemical composition of the $\alpha_{b c c}$-AlFeMnSi phase extracted from alloys 2 and 3 , also differed from that corresponding to the phase associated with the JCPDS card used, as indicated by the EDS data (Table II). This evidenced the non-stoichiometric nature of the $\alpha_{\mathrm{bcc}}-\mathrm{AlFeMnSi}$ phase formed in these alloys. The irregular and polyhedral morphologies of the $\alpha_{\mathrm{bcc}}$-AlFeMnSi phase observed on the SEM in the as-cast and in the isothermally-treated alloy 4 are shown in figures. 6 a) and $6 \mathrm{~b}$ ), respectively. Similar results were obtained for alloys 2 and 3 .

According to table II, $T_{p}$ for the $\alpha_{\mathrm{bcc}}-\mathrm{AlFeMnSi}$ phase increased with increasing iron content in the alloy. Also, the EDS data given in table II show that the Iron contained in the $\alpha_{b c c}$-AlFeMnSi phase increased, while the manganese contained decreased with increasing Iron content in the alloy. The total concentration of transition metals $(\mathrm{Fe}+\mathrm{Mn})$ in the $\alpha_{\mathrm{bcc}}-\mathrm{AlFeMnSi}$ crystals fell in the range of $31-32 \%$, when Iron was added to the alloys. The Fe/Mn weight

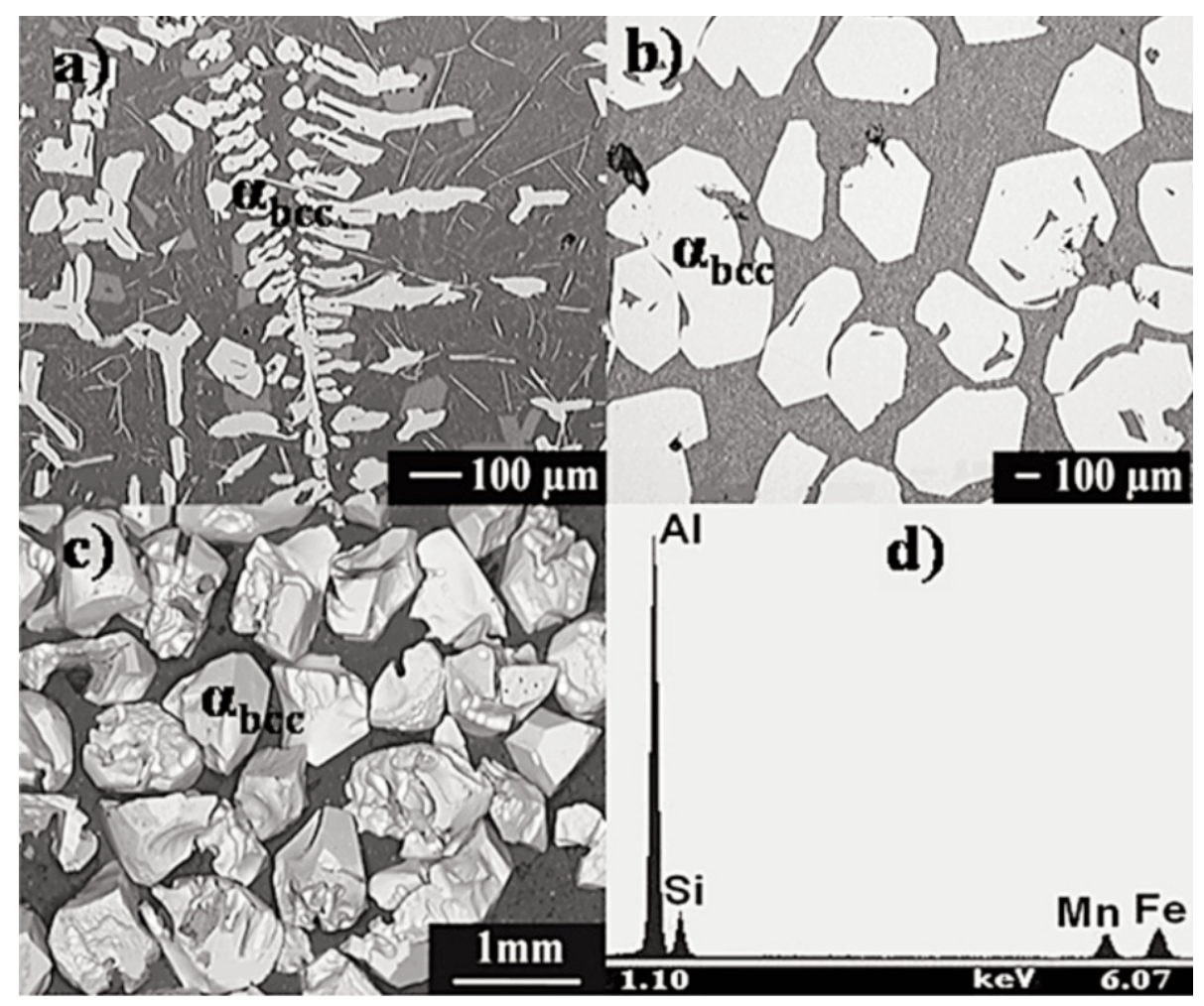

Figure 6. SEM micrographs showing the morphology of the $\alpha_{b c c}$-AlFeMnSi phase found in alloy 4 , as-cast (a), isothermally-treated at $664{ }^{\circ} \mathrm{C}(\mathrm{b})$ and of extracted $\alpha_{\mathrm{bcc}}$ particles (c). EDS spectra of extracted $\alpha_{b c c}$ particles (d).

Figura 6. Micrografías de MEB mostrando la morfología de la fase $\alpha_{c c c}$-AlFeMnSi encontrada en la aleación 4, en condición de colada (a), tratada isotérmicamente a $664^{\circ} \mathrm{C}$ (b) y partículas de $\alpha_{c c c}$ extraídas (c). Espectro de EDS obtenido de las partículas de $\alpha_{c c c}$ extraídas (d). 
ratio was in the range of $0.45-1.39$ for the extracted $\alpha_{\mathrm{bcc}}-\mathrm{AlFeMnSi}$ particles. The Fe/Mn weight ratio depended on the alloy's composition. On the other hand, the lattice parameter of the $\alpha_{\text {bcc }}-\mathrm{AlFeMnSi}$ phase decreased from $12.603 \AA$ to $12.535 \AA$ with increasing Iron contained and decreasing manganese contained in the $\alpha_{\mathrm{bcc}}-\mathrm{AlFeMnSi}$ phase (Table II). This behavior has been attributable to the substitution of manganese atoms by iron atoms ${ }^{[4}$ and 16$]$ in the lattice sites of the crystal structure.

\subsection{Hexagonal $\alpha_{h}$-AIFeMnSi phase}

The intermetallics extracted from alloys 5 through 8 , after isothermal holding at $T_{s}$ (Table II), were analyzed by XRD. Figure 7 shows the XRD pattern obtained for the intermetallic particles extracted from alloy 8 . In this case, all peaks could be indexed according to the JCPDS card number 71-0238, which corresponds to the $\mathrm{Al}_{167.8} \mathrm{Fe}_{44.9} \mathrm{Si}_{23.9}$ phase. This phase exhibits

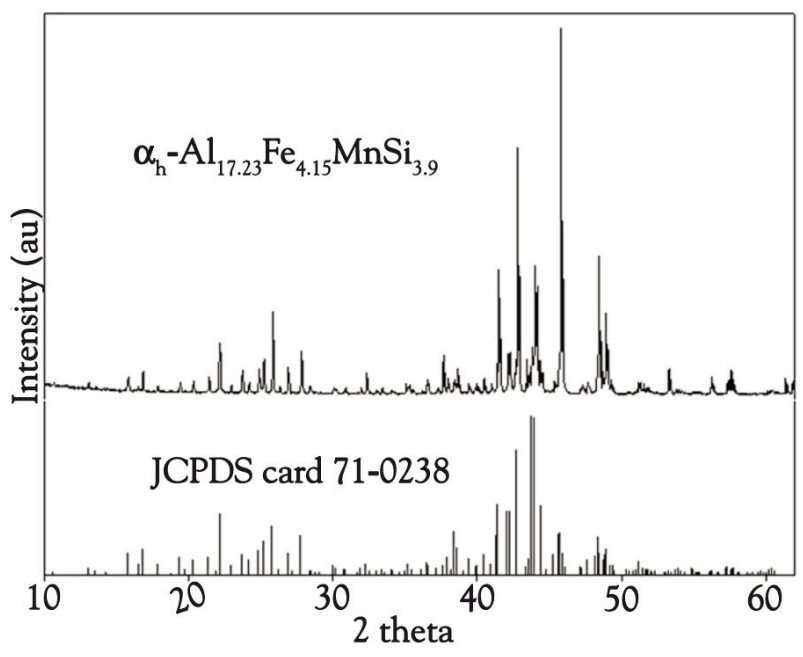

Figure 7. XRD pattern obtained for the $\alpha_{\mathrm{h}}-\mathrm{Al}_{17.23} \mathrm{Fe}_{4.15} \mathrm{MnSi}_{3.9}$ phase extracted from alloy 8.

Figura 7. Difractograma de $D R X$ obtenido de la fase $\alpha_{h}-\mathrm{Al}_{17.23} \mathrm{Fe}_{4.15} \mathrm{MnSi}_{3.9}$ extraída de la aleación 8.

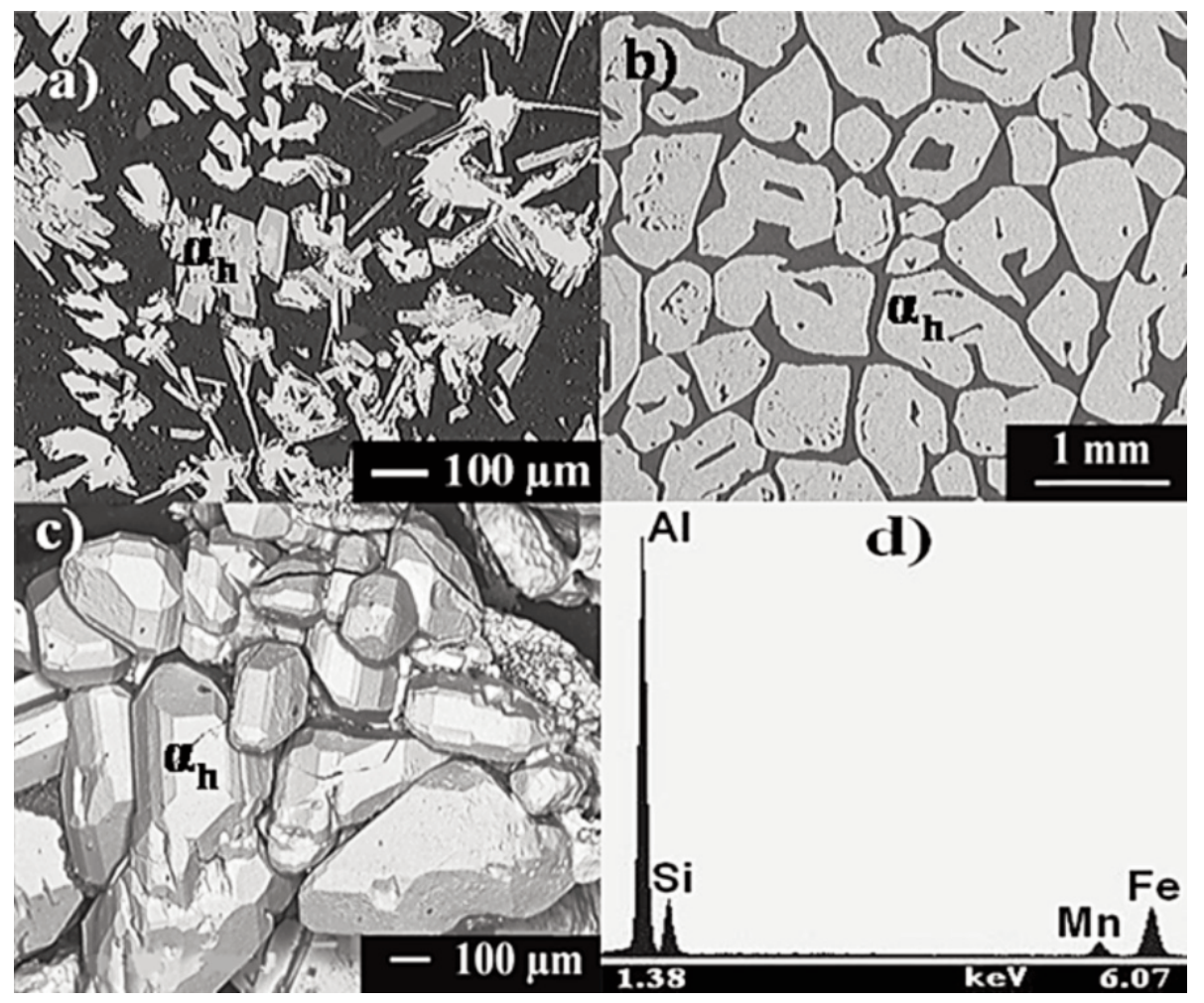

Figure 8. SEM micrographs showing the morphology of the $\alpha_{h}$-AIFeMnSi phase found in alloy 8 , as-cast (a), isothermally-treated at $722{ }^{\circ} \mathrm{C}(\mathrm{b})$ and of extracted $\alpha_{h}$ particles (c). EDS spectra of extracted $\alpha_{h}$ particles (d).

Figura 8. Micrografías de MEB mostrando la morfología de la fase $\alpha_{h}$-AlFeMnSi encontrada en la aleación 8 , en condición de colada (a), tratada isotérmicamente a $722{ }^{\circ} \mathrm{C}$ (b) y partículas de $\alpha_{h}$ extraídas (c). Espectro de EDS obtenido de las partículas de $\alpha_{h}$ extraídas (d). 
hexagonal crystal structure and belongs to the $\mathrm{P} 6_{3} / \mathrm{mmc}$ space group ${ }^{[18]}$. Again, the chemical composition of the particles extracted from alloy 8 differed considerably from that corresponding to the phase associated with the JCPDS card used to index the peaks in the XRD pattern. The extracted particles from alloy $8 \mathrm{had}$ a chemical composition corresponding to the $\alpha_{\mathrm{h}}-\mathrm{Al}_{17.2} \mathrm{Fe}_{4.15} \mathrm{MnSi}_{3.9}$ formula, according to the EDS data given in table II. Similar results in chemical composition were obtained for the $\alpha_{\mathrm{h}}$-AlFeMnSi phase formed in alloys 5 to 7 . The irregular and polyhedral morphologies of the $\alpha_{h}$-AlFeMnSi phase observed by SEM in the as-cast and in the isothermally-treated alloy 8 are shown in figures. 8 a) and 8 b), respectively. Similar intermetallic morphologies were observed for alloys 5,6 and 7 .

According to table II, $T_{p}$ for the $\alpha_{h}$-AlFeMnSi phase increased from 702 up to $745^{\circ} \mathrm{C}$ with increasing Iron content in the alloy. Moreover, the total concentration of transition metals $(\mathrm{Fe}+\mathrm{Mn})$ in the precipitated particles varies between $33 \%$ and $34 \%$ under the same circumstances, i.e., $2 \%$ more than the corresponding values observed in the case of the $\alpha_{\mathrm{bcc}}$-AlFeMnSi phase. The Fe/Mn weight ratio in the $\alpha_{\mathrm{h}}$-AlFeMnSi phase was in the range of 3.41-4.45, depending on the alloy's composition. The lattice parameters of the $\alpha_{h}$-AlFeMnSi phase decreased with increasing Iron content in the alloys 5 to 8 (Tables I and II).

In general, our results indicate that for the studied alloys, the critical Fe/Mn weight ratio is between 4 and 5.3 for the transition from the bcc to the hexagonal crystal structure in the formed $\alpha$-AlFeMnSi phases. Nonetheless, according to both the literature review and these results, the critical Fe/Mn weight ratio can change depending on the silicon, iron and manganese contents of the alloy, which is evident when the results reported by Tibballs et al. ${ }^{[12]}$ are considered.

\section{CONCLUSIONS}

- The $\alpha$-AlFeMnSi phase, precipitated during solidification of the studied alloys, presents three types of crystal structure: sc (alloy 1), bcc (alloys 2 to 4 ) and hexagonal (alloys 5 to 8). Furthermore, it was found that the $\alpha_{b c c}-A 1 F e M n S i$ and $\alpha_{h}$-AlFeMnSi phases are not stoichiometric in nature because in both cases the chemical composition of the $\alpha$-AlFeMnSi phases depends on the alloy's composition. Thus, the use of a general formula to describe them is not justified.

- The critical Fe/Mn weight ratio, in the studied alloys, was between 4 and 5.3 for the bcc to hexagonal crystal structure transition in the formed $\alpha$-AlFeMnSi phases. Nonetheless, according to the literature review and to these results, the critical Fe/Mn weight ratio can change depending on the silicon, iron and manganese contents of the alloy. Also, the $\mathrm{Fe} / \mathrm{Mn}$ weight ratio in the chemical composition of the formed $\alpha$-AlFeMnSi phases depended on the crystal type; it was $0.45-1.39$ for the $\alpha_{\mathrm{bcc}}-\mathrm{AlFeMnSi}$ phase and 3.41-4.45 for the $\alpha_{h}$-AlFeMnSi phase. The formation of the $\alpha_{\text {sc }}$-AlFeMnSi phase was observed only in the case of alloy 1 with a Fe/Mn weight ratio of 0.1 .

\section{Footnotes}

All chemical compositions are given in weight percent, unless otherwise specified.

\section{Acknowledgements}

The authors are grateful to the National Council for Science and Technology of México (CONACYT) for the financial support provided to carry out this work (project no. 84966).

\section{REFERENCES}

[1] R.S. Preston and R. Gerlach, Phys. Rev. B. 3 (1971) 1519-1526.

[2] V. Stefaniay, A. Griger, T. Turmezey, J. Mater. Sci. 22 (1987) 539-546.

[3] P.N. Crepeau, AFS Transactions, 103 (1995) 361-366.

[4] N.C.W. Kuijpers, F.J. Vermolen, C.Vuik, P.T.G. Koenis, K.E. Nilsen and S. van Zwaag, Mater. Sci. Eng. A394 (2005) 9-19.

[5] M.V.Kral, P.N.H. Nakashima and D.R.G. Mitchell, Metall. Mater. Trans. A 37A (2006) 1987-1997.

[6] Mondolfo L.F., Aluminum Alloys: Structure and Properties, Butterworths and Co., Ltd, London, 1976, pp. 25-53.

[7] V.G. Rivlin and G.V. Raynor, Int. Met. Rev. 26, (1981), 133-152.

[8] G. Ghosh, Aluminium-Iron-Silicon. G. Effenberg, S. Ilyenko, Landolt-Börnstein, New Series IV/11D1, Springer, Berlin 2008, pp. 1-83.

[9] E.L. Rooy, AFS Transactions, 93 (1985) 935-938.

[10] J.G. Barlock and L.F. Mondolfo, Z. Metallk. 66 (1975) 605-611.

[11] A.M. Zakharov, I.T. Gul'din, A.A. Arnol'd, and Yu. A. Matsenko, Metall. 4 (1989) 214-218. 
[12] J.E. Tibballs, J.A. Horst and C.J. Simensen, J. Mater. Sci. 36 (2001) 937-941.

[13] C. Ravi and C. Wolverton, Metall. Mater. Trans. A, 36A (2005) 2013-2023.

[14] L. Bäckerud, G. Chai and J. Tamminen, Solidification Characteristics of Aluminum Alloys, AFS/Skanaluminium, vol. 2, Stockholm, Sweden, 1990, pp. 71-210.
[15] M. Cooper and K. Robinson, Acta Crystallogr., 20 (1966) pp. 614-617.

[16] P.J. Schurer, B. Koopmans and F. Van der Woude, Phys. Rev. B. 37 (1988) 507-510.

[17] M. Cooper, Acta Crystallogr. 23 (1967) 1106-1107.

[18] R.N. Corby and P.J. Black, Acta Crystallogr., B, 33 (1977) 3468-3475. 


\section{FE DE ERRATAS}

Volumen 47, Número 6, Noviembre-Diciembre 2011:

Pág. 453.- En la edición impresa del artículo "Effect of iron addition on the crystal structure of the a-AlFeMnSi phase formed in the quaternary Al-Fe-Mn-Si system", el apellido del autor "J. López-Rueda" debe corregirse a "J. López-Cuevas".

La errata ya figura corregida en la edición electrónica del artículo. [28 de marzo 2012]

\section{ERRATUM}

Volume 47, Issue 6, November-December 2011

Pag. 453. In the printed edition of the article entitled "Effect of iron addition on the crystal structure of the a-AlFeMnSi phase formed in the quaternary Al-Fe-Mn-Si system" the author's surname "J. López-Rueda" should be corrected to "J. LópezCuevas"

This erratum is already corrected in the online edition of the article. [28 March 2012] 